\title{
Study of Transfer Properties on Fresh Cement Pastes; Laboratory Experiments: Discontinue Measurements using a Permeameter
}

\author{
Jean Claude Tchamba ${ }^{1,2}$ \& Théodore Gautier L. J. Bikoko ${ }^{3}$ \\ ${ }^{1}$ Mechanical Engineering and Materials Laboratory, University of South Brittany, Lorient, France \\ ${ }^{2}$ Civil Engineering Laboratory, ENSET, University of Douala, P.O. Box: 1872, Douala, Cameroon \\ ${ }^{3}$ School of Civil and Environmental Engineering, University of The Witwatersrand, Johannesburg, South Africa \\ Correspondence: Théodore Gautier L. J. Bikoko, School of Civil and Environmental Engineering, University of \\ The Witwatersrand, Johannesburg, South Africa. Tel: 27-792-787-723. E-mail: lejeunegautier@rocketmail.com
}

Received: November 26, 2015 Accepted: December 4, 2015 Online Published: January 14, 2016

doi:10.5539/jmsr.v5n2p29

URL: http://dx.doi.org/10.5539/jmsr.v5n2p29

\begin{abstract}
The study of hydraulic conductivity or permeability $(\mathrm{k})$ of fresh cement pastes is a fundamental stage to understand the concrete placement in their formworks, and for the more extended study of the rheology of cementitious materials at fresh state. The results here are obtained on fresh cement pastes (PC) PC30, PC36 and PC40 with water- to- cement ratio $(\mathrm{w} / \mathrm{c})$ of $0.30,0.36$ and 0.40 respectively with a classical permeameter traditionally used in geotechnical for soil permeability measurements: the constant head permeameter. It has the advantage of allowing accurate measurements and staggered over time. The analysis of results obtained are in agreement with those obtained elsewhere in the literature.
\end{abstract}

Keywords: Cementitious materials, Fresh cement pastes, Permeability, Water/cement ratio

\section{Introduction}

Cement is a basic construction material, and the hydraulic cement known is Portland cement. Hydraulic cement set and harden as a result of hydration reactions between water and compounds in the cement, developing both strength and stiffness over time (Bolton \& Mckinley, 1997).

Fresh cement pastes and generally fresh cement-based materials are suspensions of grains in a liquid phase (Perrot, Rangeard, Picandet, \& Mélinge, 2013).

Hydraulic conductivity or simply permeability $(\mathrm{k})$ of freshly mixed cementitious-based materials is a key indicator to understand the hydro-mechanical properties (i.e., static stability, pumping, formwork pressure, plastic shrinkage) and their evolution with time (Picandet, Rangeard, Perrot, \& Lecompte, 2011; Assaad \& Harb, 2013). However, its permeability measurement is not easy to assess: The porous media is not rigid and tends to change due to hydration kinetic (Picandet et al., 2011).

The notion of permeability has been mostly developed in soil mechanics (Assaad \& Harb, 2013) to evaluate the ease with which fluid moves through the tortuous path of a solid skeleton with interconnected voids (Das, 2010; Assaad \& Harb, 2013). Such measurement can be used for stability analyses of earth and retaining structures (Assaad \& Harb, 2013), to quantify the liquid filtration rate under a given pressure gradient, to evaluate the interstitial fluid transport properties as it links the liquid flow rate to the pressure gradient (Pierre, Perrot, Picandet, \& Guevel, 2015), to predict the amount of bleed water using consolidation theory (Rangeard, Perrot, Picandet, Mélinge, \& Estellé, 2015 ; Assaad \& Harb, 2011; Josserand, Coussy, \& de Larrard, 2006 ; Josserand \& de Larrard, 2004 ; Yim, Kim, Kwak, \& Kim, 2013), to give drainage criteria for various concrete casting and pre-casting procedure (Pierre et al., 2015 ; Perrot, Lanos, Estellé, \& Mélinge, 2006), to predict the drying kinetic after casting (Bentz, Hansen, Madsen, Vallée, \& Griesel, 2001) and to estimate the quantity of under- ground seepage under various hydraulic conditions (Assaad \& Harb, 2013).

Since cementitious materials are bi-phasic containing colloidal grains, it is possible to use the soil mechanics concepts for a theoretical basis to understand in more detail the hydro-mechanical behaviour of the material (Perrot, 2014). 
The determination of the permeability of fresh cement pastes have already been the subject of previous studies (Hendrickx, Roels, \& Van Balen, 2010; Appleby \& Wilson,1996; Picandet et al., 2011; Assaad \& Harb, 2011; Marliere, Mabrouk, Lamblet, \& Coussot, 2012) using imbibition tests, traditional filtration tests, drying tests, water retention tests or controlled oedometer.

In this study a classical permeameter traditionally used for soil permeability measurements was used for testing. The tests were carried out on fresh cement pastes PC 30, PC36 and PC40 with w/c ratio of $0.30,0.36$ and 0.40 respectively.

The permeability of the fresh cement pastes is studied. The evolution of the hydraulic conductivities is also studied. The influence of the pressure gradient and the $\mathrm{w} / \mathrm{c}$ ratio on the hydraulic conductivity is investigated, after which conclusions are drawn.

\section{Materials and Methods}

\subsection{Materials}

Type 1 Ordinary Portland Cement of strength class 52.5 Mpa at 28 days (CEM I 52.5 N CE CP2 NF) procured from cement manufacturing company of St Pierre la Cour (Lafarge, France) was used for all experiments. The cement size distribution was ranges between 0 and $100 \mu \mathrm{m}$. The specific blaine surface was $3520 \mathrm{~cm}^{2} / \mathrm{g}$. Table 1 and 2 give chemical and mineralogical compositions respectively. The proportions of the main four phases $\left(\mathrm{C}_{3} \mathrm{~S}\right.$, $\mathrm{C}_{2} \mathrm{~S}, \mathrm{C}_{3} \mathrm{~A}$ and $\mathrm{C}_{4} \mathrm{AF}$ ) of cement were calculated using the Bogue's formulae. The Portland cement (CEM I 52.5 N CE CP2 NF) contains $95 \%$ of clinker, $2 \%$ limestone, and $3 \%$ filler.

The particle size analysis of cements were carried out by Lafarge Group, Lorient, France. Figure 1 gives the particle size distribution curve. The observation of the cement structure was analyzed (Figure 2) with the scanning electron microscope (SEM) of the University of South Brittany, Lorient, France. It has allowed us to know through the mineralogical analysis, the minerals found in dry cement.

Table 1. Chemical composition of Portland cement (CEM I 52.5 N CE CP2 NF ) used

\begin{tabular}{cc}
\hline Oxides & Content, (\%) \\
\hline $\mathrm{SiO}_{2}$ & 20.70 \\
$\mathrm{Al}_{2} \mathrm{O}_{3}$ & 4.70 \\
$\mathrm{Fe}_{2} \mathrm{O}_{3}$ & 3.00 \\
$\mathrm{CaO}$ & 64.70 \\
$\mathrm{MgO}$ & 0.90 \\
$\mathrm{~K}_{2} \mathrm{O}$ & 0.98 \\
$\mathrm{Na}_{2} \mathrm{O}$ & 0.16 \\
$\mathrm{SO}_{3}$ & 3.30 \\
$\mathrm{P}_{2} \mathrm{O}_{5}$ & 0.35 \\
$\mathrm{Cl}$ & 0.02 \\
\hline
\end{tabular}

Table 2. Phase composition (\%) by Bogue formula

\begin{tabular}{cc}
\hline Compound & Mass Percentage \\
\hline $\mathrm{C}_{3} \mathrm{~S}$ & 52.71 \\
$\mathrm{C}_{2} \mathrm{~S}$ & 17.86 \\
$\mathrm{C}_{3} \mathrm{~A}$ & 8.20 \\
$\mathrm{C}_{4} \mathrm{AF}$ & 8.35 \\
\hline
\end{tabular}



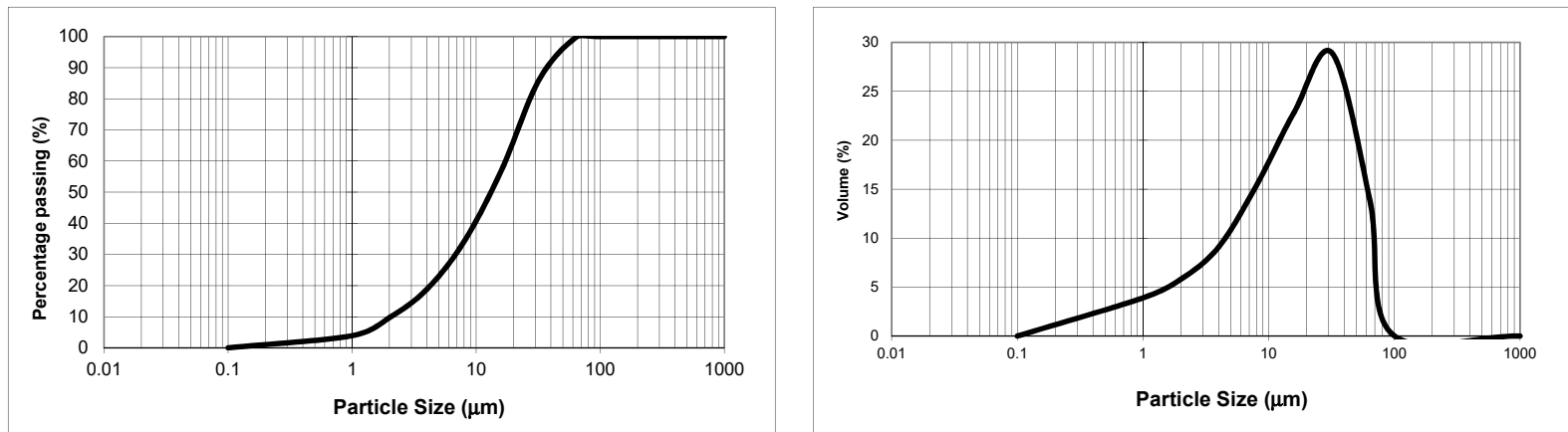

Figure 1. Particle size distribution curve of CPA CEM I 52.5 CP2

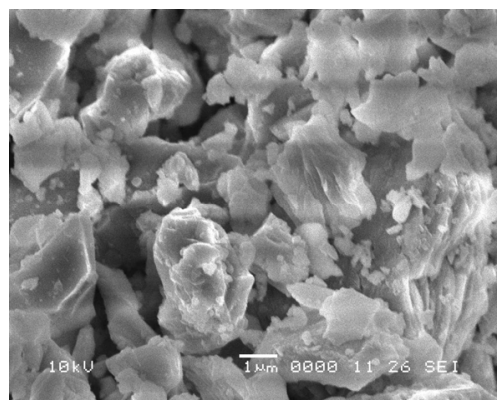

Figure 2. SEM micrograph of CEM I 52.5 N CE CP2 NF

\subsection{Methods}

\subsubsection{Sample preparation}

Each mixture (PC30, PC36 and PC40) tested was prepared in a 5 liters mixer described according to French/European standard (NF EN 196-1) shown in Figure 3. It has a stainless steel tank of 5 liters capacity and a rotatable pale press in light alloy for mixing which can run at slow speed of $140 \mathrm{rpm}$ and fast of $285 \mathrm{rpm}$.

The mixing procedure adopted for the cement paste was : distilled water was introduced in $50 \mathrm{~s}$ into the cement and mixed for 2 minutes at $140 \mathrm{rpm}$. After a rest period of $30 \mathrm{~s}$, the cement paste was remixed for 3 additional minutes at $285 \mathrm{rpm}$ (Tchamba, 2008 ; Josserand, 2002 ; Dupain, Lanchon, \& Saint Arroman, 1995). The mixture proportions of the fresh cement pastes studied in this experimental program are listed in Table 3 . The main difference among these fresh cement pastes is their w/c.

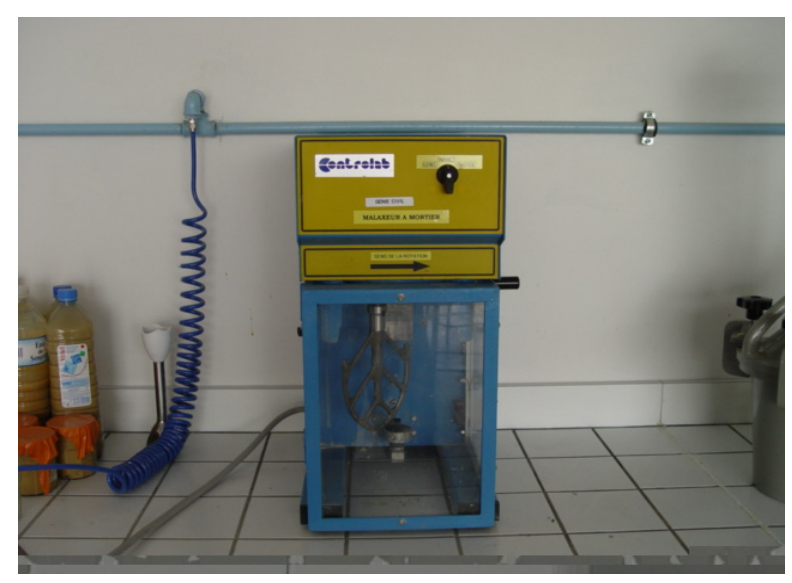

(a)

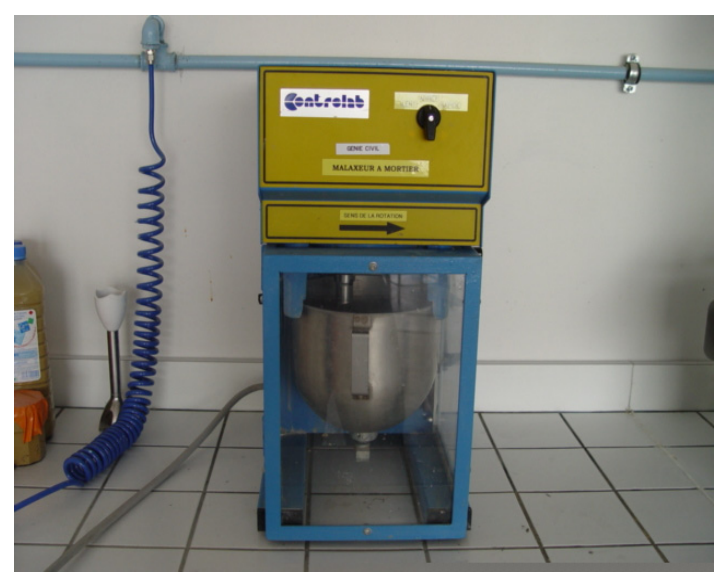

(b)

Figure 3. Classical mixer for cement paste provided with pale press (a) and the vessel (b) 
Table 3. Mixture proportions for the fresh cement pastes used in the tests

\begin{tabular}{lllll}
\hline Mixture & $\mathrm{W}\left(\mathrm{l} / \mathrm{m}^{3}\right)$ & $\mathrm{C}\left(\mathrm{Kg} / \mathrm{m}^{3}\right)$ & $\mathrm{W} / \mathrm{C}$ & $\rho\left(\mathrm{Kg} / \mathrm{m}^{3}\right)$ \\
\hline PC 30 & 487 & 1622 & 0.30 & 2109 \\
PC 36 & 532 & 1478 & 0.36 & 2010 \\
PC 40 & 558 & 1396 & 0.40 & 1954
\end{tabular}

Note: $\mathrm{PC}=$ Fresh cement paste, $\mathrm{W}=$ Water, $\mathrm{C}=$ Cement, $\mathrm{W} / \mathrm{C}=$ Water $/$ Cement, $\rho=$ Density.

\subsubsection{Experimental Procedure}

The experiments were conducted in the Mechanical Engineering and Materials Laboratory of University of South Brittany, Lorient, France. A classical permeameter (Figure 4) traditionally used for soil permeability measurements was used for testing. The apparatus consists mainly of a cell of $795 \mathrm{~cm}^{3}(10.2 \mathrm{~cm}$ of diameter and $10 \mathrm{~cm}$ of height) in which we introduced the fresh cement paste and a balance of accuracy of $0.01 \mathrm{~g}$ was used to weigh water squeezing out of the sample (Amziane, 2005). The cell is provided on its top part of a pressurized air inlet and on its bottom part equipped with a valve connected to a filter for evacuating water from the sample. A pressure sensor is connected to the pressurized air inlet to monitor pressure. Prior to testing, the filtration system i.e., filter paper and grid was saturated. The fresh cement pastes are then introduced into the cell in 4 layers of equal depth, tamping each layer with 25 strokes with the tamping rod. The tamping rod is that used for the slump test to Abram's cone (NF P 18-451). On top of the sample, $160 \mathrm{~g}$ of water was added to keep the sample fully saturated throughout the test period. The water used was from the Mechanical Engineering and Materials Laboratory tap of University of South Brittany, Lorient, France. The tests were performed at controlled temperature of $20 \pm 2^{\circ} \mathrm{C}$ and $60 \%$ relative humidity. The hydraulic conductivities measured thereafter are related to this temperature. The water pressure applied on the top surface of the sample was high enough to allow the flow of water without leading to breakdown by shearing (Amziane, 2005). For this reason we applied a pressure of $30 \mathrm{kpa}$ because higher pressure than this cause the fresh cement paste to break (Amziane \& Andriamanantsilavo, 2004) and kept constant for a hydration time of 15 minutes until the end of the test. The maximum total time to prepare the mix (i.e., cement pastes), place in the cell, and testing permeability was approximately 290 minutes.

The principle consists of measuring the amount of water that is squeezed out from the bottom surface of the sample for 15 seconds using a balance. Before measurement of each flow, we proceed to a dewatering for 2 seconds with the aim of standardizing the pressure gradient within the cell.

From the volume of water obtained during the 15 seconds remaining during which the flow rate is stabilized, the average flow rate was deduced and the global hydraulic conductivity of the tested sample was calculated using Darcy's law (see Equation (3)).

Darcy's law has been used for prediction of permeability of cement paste for decades (Powers, Copeland, Hayes, \& Mann 1955; Mehta \& Manmohan, 1980 ; Hughes, 1985 ; Ye, 2003). Originally, Darcy's law defines the permeability in terms of measurable macroscopic quantities and states that the steady-state rate of laminar flow in capillary pores in saturated condition through a porous medium is directly proportional to the hydraulic gradient (Ye, 2003) i.e.:

$$
Q=A \frac{\kappa \rho g}{\mu} \frac{\Delta h}{L}
$$

Where $Q=$ the volume of fluid passed in unit time, $\mathrm{m}^{3} / \mathrm{s}$,

$\mathrm{A}=$ cross-sectional area of the sample in $\mathrm{m}^{2}$,

$\Delta \mathrm{h}=$ drop in hydraulic head through the sample, measured in $\mathrm{m}$,

$\mathrm{L}=$ thickness of the sample in $\mathrm{m}$,

$\mu=$ dynamic viscosity of the fluid in $\mathrm{N} \mathrm{s} / \mathrm{m}^{2}$,

$\rho=$ density of the fluid in $\mathrm{kg} / \mathrm{m}^{3}$, and

$\mathrm{g}=$ gravitational acceleration $\left(9.81 \mathrm{~m} / \mathrm{s}^{2}\right)$. 
The coefficient $\kappa$ is the intrinsic permeability with dimensions of area $\left(\mathrm{m}^{2}\right)$. It is the most rational concept of permeability, as it depends purely on the characteristics of the porous medium and is independent of the fluid involved (Neville, 1995; Ye, 2003).

If the fluid involved is water, the relationship between the intrinsic permeability and the water permeability coefficient $\mathrm{k}_{\mathrm{w}}$ was given by Muskat (1937) and Ye (2003):

$$
k_{w}=\frac{\rho g}{\mu} \cdot \kappa
$$

For water at $20{ }^{\circ} \mathrm{C}$, the conversion coefficient $\rho \mathrm{g} / \mu$ equals $9.76 \times 10^{-6} \mathrm{~m}^{-1} \mathrm{~s}^{-1}$. The dimensions of the water-permeability coefficient $\mathrm{k}_{\mathrm{w}}$ is $(\mathrm{m} / \mathrm{s})$. When a steady-state of flow $\mathrm{Q}$ has been reached, the coefficient of permeability of the porous medium can be determined directly by combining Equation1 and Equation 2:

$$
k_{w}=\frac{L Q}{A \Delta h}
$$

Under pressure, the maturation probably led to lower porosity thus lower permeability. To test this hypothesis, we applied, as before, for greater times of 15 minutes, two different protocols:

a) the pressure is applied at the time of the beginning of the test.

b) the pressure of $30 \mathrm{kPa}$ is applied for a hydration time of 15 minutes and is kept constant until the end of the test.

Note: The items with ' ${ }^{*}$ ' in the figure indicate that the sample was subjected to a pressure of $30 \mathrm{kPa}$ until the end of the test.

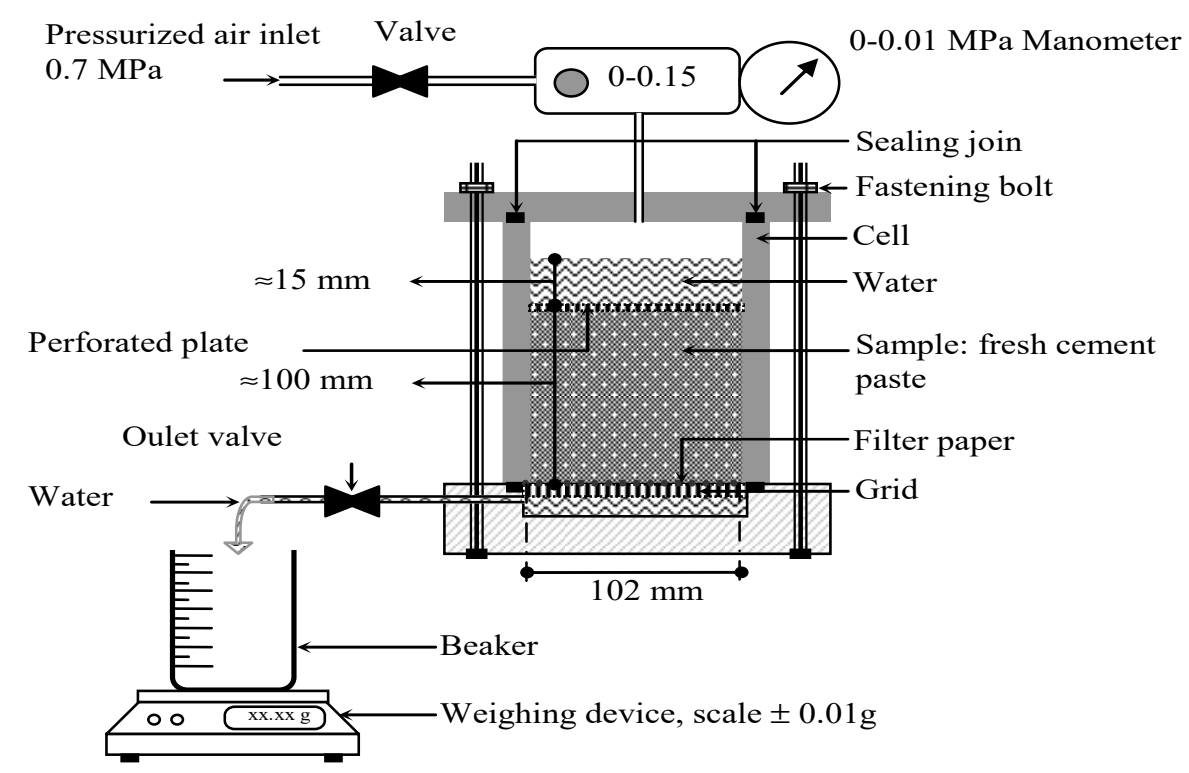

Figure 4. Schematic representation of the constant head permeameter (Tchamba, 2008 ; Amziane, 2005 ; Picandet, Amziane, \& Tchamba, 2005)

\section{Results and Discussion}

Figure 5 shows the cumulative volume of water collected for four differed tests according to the hydration times of $15 \mathrm{mins}, 1 \mathrm{hr}, 2 \mathrm{hrs}$ and $3 \mathrm{hrs}$ for mixture with a w/c ratio of 0.36 .

For the 3 mixtures (PC 36 at 15 mins, PC36 at $1 \mathrm{hr}$ loaded and unloaded, PC36 at $2 \mathrm{hrs}$ loaded and unloaded and PC36 at $3 \mathrm{hrs}$ loaded and unloaded) studied, it appears that the percolation rate decreases with time:

- It decreases during a procedure of a discontinue test, the curve of the cumulative water volume bends.

- When the test procedures are shifted in time (from the initial time of hydration of the paste), the volume of water percolating decreases with time of hydration of fresh cement paste. 
For a given hydration time, it appears that the preliminary pressurization has the effect of reducing the volume of water percolated. The relative effect of this decrease appears to increase with time.

From the evolution of accumulated volumes presented in Figure 5, the percolation flow rates at each sequence are deduced and hydraulic conductivities are calculated (see Equation [3]) and presented in Figure 6 according to the hydration time in the test procedure.

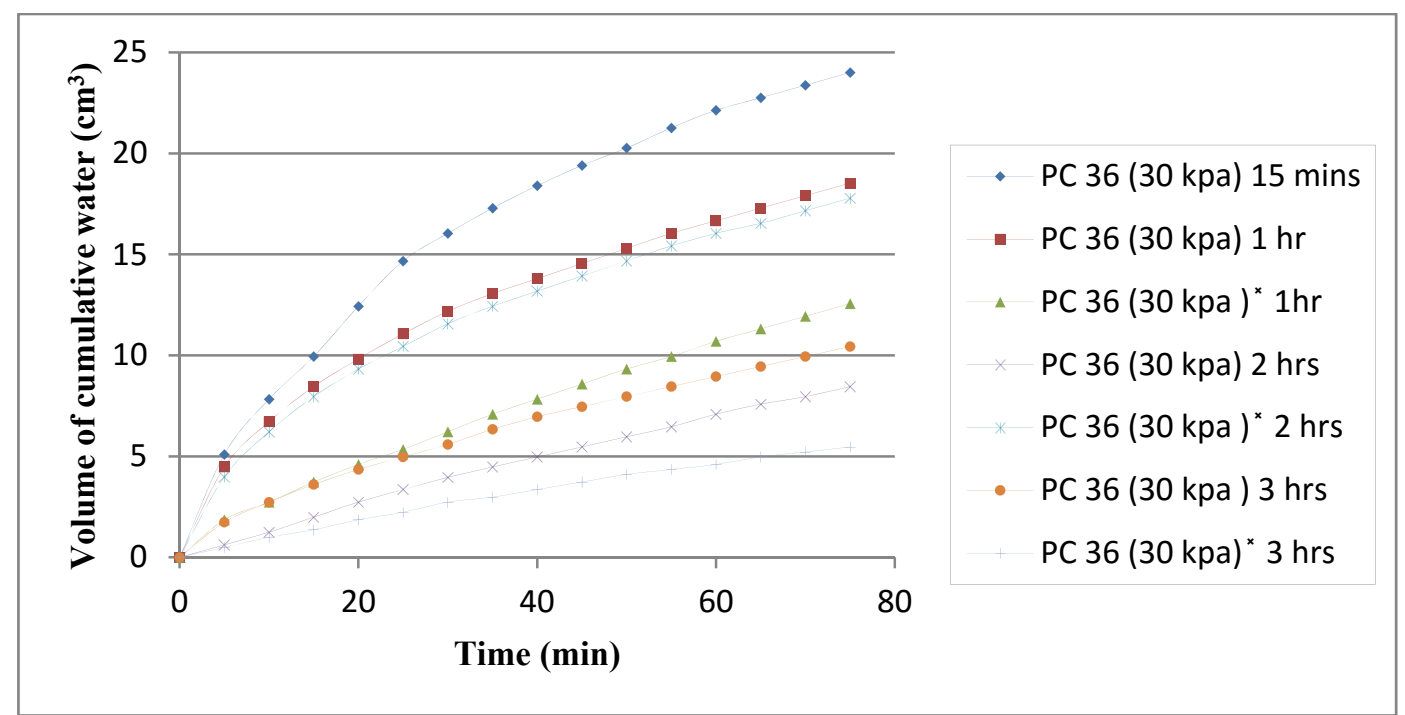

Figure 5. Evolution of the cumulative volume of water collected under the discontinue percolation process for mixture with a w/c ratio of 0.36

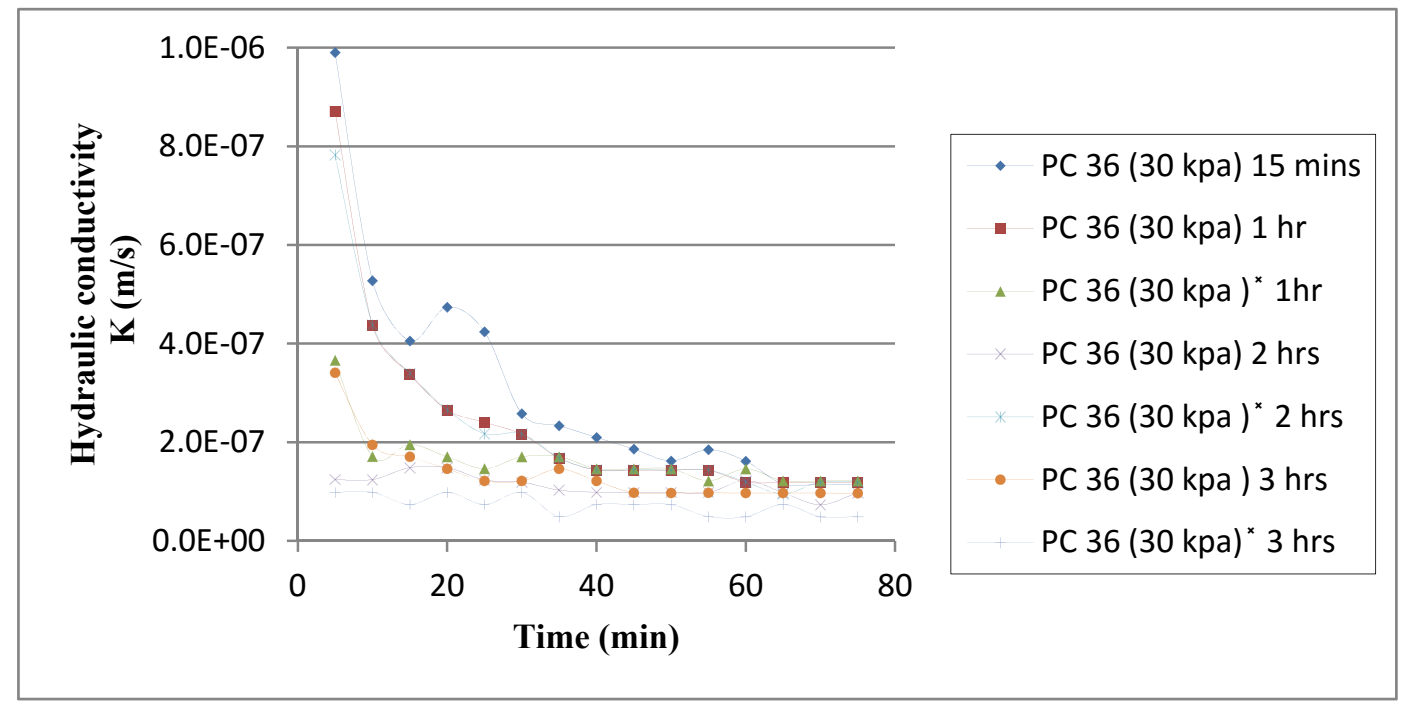

Figure 6. Hydraulic conductivities evolution deduced of each stage of percolation for mixture with a w/c $=0.36$ at different hydration times

\subsection{Hydraulic Conductivities Evolution}

Figures 7 and 8 show on the other hand the evolution of the hydraulic conductivity of the fresh cement pastes of $\mathrm{w} / \mathrm{c}=0.30$ and 0.40 respectively as a function of the hydration time of the paste. Hydraulic conductivity measurements derived from the same procedure are linked by a line. In some hydration time thus correspond to 2 hydraulic conductivity measurements relating to overlapping test procedures for the same hydration time.

It appears that the hydraulic conductivity calculated from the flow rates achieved at the end of a 75 minutes test is lower than the first hydraulic conductivities obtained for an offset test of 2 hours. This suggests that despite the 
minimized percolation time during this test procedure, the permeability of the sample is changed during the test. This is mainly due to the percolation of water which leads to a change in the porosity, by moving or dragging fine particles even for a percolation period not exceeding 4 minutes.

For tests carried out on fresh cement pastes having a longer hydration time greater than 2 hours, the relative decrease of the hydraulic conductivity is much less sensitive even negligible. This suggests that for longer hydration time, the paste is more stable, percolation of water is certainly less important, since hydraulic conductivity is lower, but the fine particles are also likely to be less mobile and can be linked more strongly to the matrix.

It is interesting to note that the maximum hydraulic conductivities which is calculated at the beginning of each test procedure, which is the most significant of an intact fresh cement paste sample, tends to greatly decrease over time whenever the $\mathrm{w} / \mathrm{c}$ ratio of the fresh cement pastes.

On the contrary, the lowest hydraulic conductivities, recorded at the end of the test procedure, following which a decrease was less pronounced in the period of 2 to 4 hours, particularly for paste with high w/c ratio, for which the mobility of the fine particles are larger. These may be a filter cake, which increases the global hydraulic conductivity of the sample.

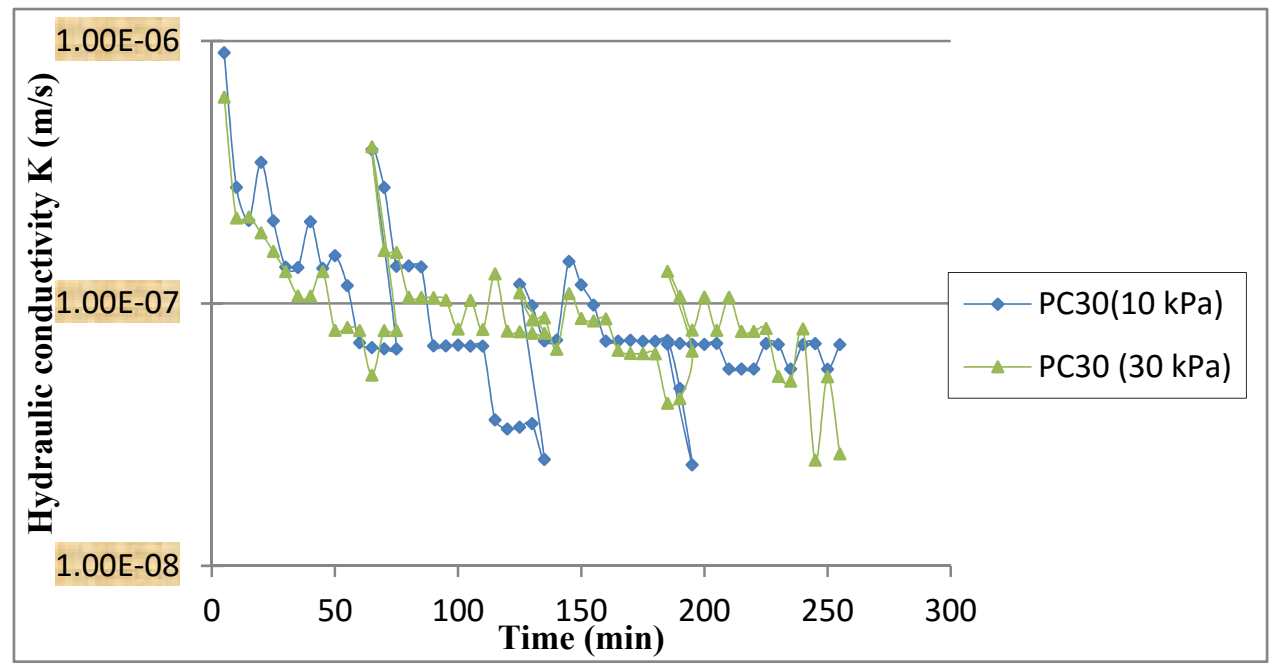

Figure 7. Hydraulic conductivities evolution deduced from each stage of percolation as a function of hydration time for mixture with a w/c $=0.30$ subjected to a pressure of $10 \mathrm{kPa}$ and $30 \mathrm{kPa}$

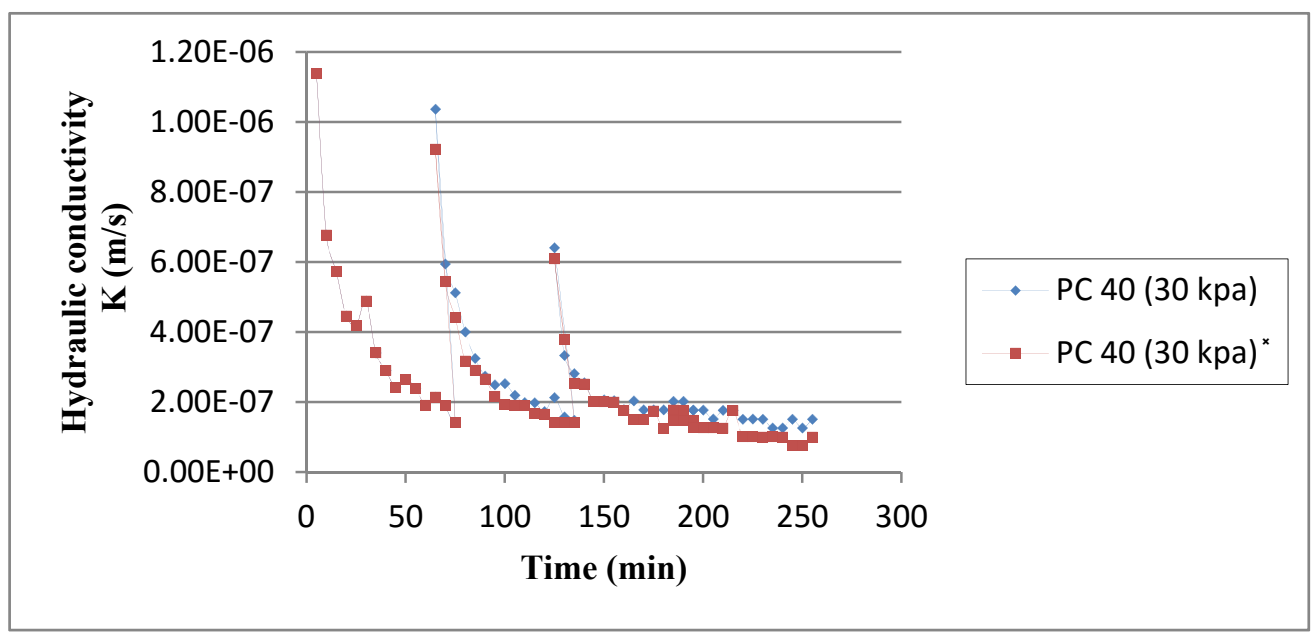

Figure 8. Evolution of hydraulic conductivities deduced from each stage of percolation for 4 consecutive and reported tests as a function of hydration time for mixture with a $\mathrm{w} / \mathrm{c}=0.40$ undergoing waiting phase subjected and non-subjected to a pressure of $30 \mathrm{kPa}$ 


\subsection{Influence of the Pressure Gradient Exerted on Sample}

The comparison test was carried out on a mixture with a $\mathrm{w} / \mathrm{c}=0.30$, respectively subjected to a pressure gradient of $10 \mathrm{kPa}$ and $30 \mathrm{kPa}$. From Figure 7, we can observe that the difference between the two tests is small which indicates that the pressure gradient has no significant influence on hydraulic conductivity deduced from the filtration tests. This point confirms the validity of Darcy's law for our type of experience. Subsequently, we applied a pressure of $30 \mathrm{kPa}$ for all tests to obtain more flow and thus better accuracy and a higher pressure than $30 \mathrm{kPa}$ cause the fresh cement paste to break (Amziane \& Andriamanantsilavo, 2004).

\subsection{Influence of $w / c$ Ratio}

Figure 9 shows that for four procedures of discontinue test, the global hydraulic conductivity of the sample tends to increase with the $\mathrm{w} / \mathrm{c}$ ratio, whenever the age of hydration time of the paste. This difference is however more pronounced for longer hydration time and for measurements made at the end of procedure.

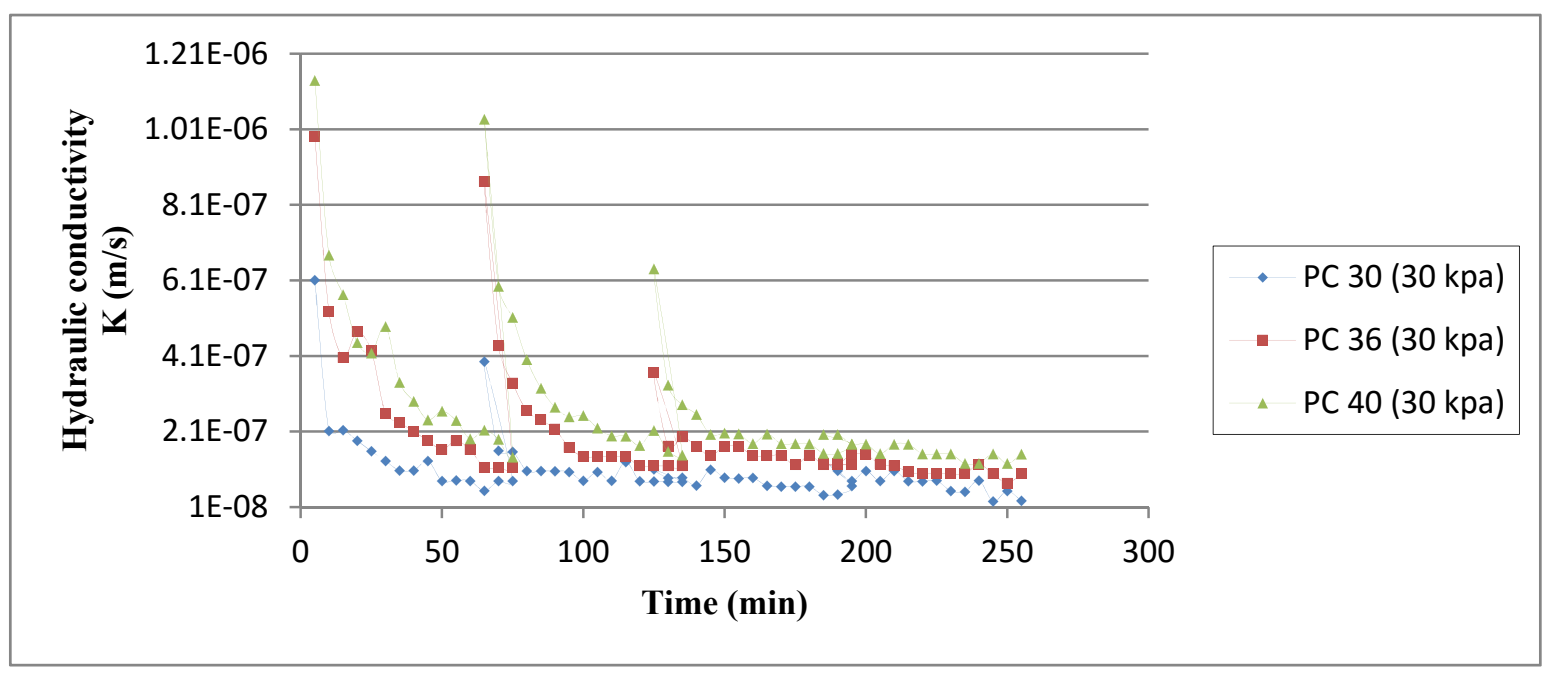

Figure 9. Hydraulic conductivities evolution deduced from each stage of percolation for 4 consecutive and reported tests as a function of hydration time for mixtures with a w/c $=0.30 ; \mathrm{w} / \mathrm{c}=0.36$ and $\mathrm{w} / \mathrm{c}=0.40$

\section{Conclusion and Perspectives}

Hydraulic conductivity of the fresh cement pastes decrease significantly during a procedure of discontinue test. For an identical hydration time, it does not measure the same hydraulic conductivity depending on whether the measurement was effected at the beginning or end of the procedure. Therefore, despite the time and the percolated volumes minimized, the sample undergoes a change in porous structure due to the circulation of water which increases its global hydraulic conductivity.

However, from the first measurements the hydraulic conductivity of the samples decrease significantly with time of hydration. Increasing the w/c ratio in the range between 0.30 and 0.40 tends to increase the global hydraulic conductivity of fresh cement pastes.

The hydraulic conductivities relatives of the first measurements of each series tend to decrease in the first hours of hydration, while those relating to the last measurements of each series (after formation of a filtration cake) remain roughly stable during the first four hours. Beyond, the setting phenomena commence, and the hydraulic conductivity of fresh cement pastes suddenly drops.

\section{References}

Amziane, S. (2005). Contribution à l'etude des matériaux cimentaires à l'etat frais, HDR. Materials. Université de Bretagne Sud, Lorient, France. Retrieved from https://tel.archives-ouvertes.fr/tel-00069705/document

Amziane, S., \& Andriamanantsilavo, N. (2004). Prediction of cement paste pore water pressure variations during setting pressure. Advances in Cement Research, 16(1), 23-28. http://dx.doi.org/10.1680/adcr.2004.16.1.23

Appleby, S., \& Wilson, A. (1996). Permeability and suction in setting cement. Chemical Engineering Science, 51, 251-267. http://dx.doi.org/10.1016/0009-2509(95)00260-X 
Assaad, J. J., \& Harb, J. (2013). Use of the Falling-head Method to Assess Permeability of Freshly Mixed Cementitious-based Materials. Journal of Materials in Civil Engineering, 25(5), 1-11. http://dx.doi.org/10.1061/(ASCE)MT.1943-5533.0000630

Assaad, J. J., \& Harb, J. (2011). Surface settlement of cementitious-based materials determined by oedometer testing. Materials and Structures, 44, 845-856. http://dx.doi.org/10.1617/s11527-010-9671-z

Bentz, D., Hansen, K., Madsen, H., Vallée, F., \& Griesel, J. (2001). Drying/hydration in cement pastes during curing. Materials and Structures, 34, 557-565. http://dx.doi.org/10.1007/BF02482182

Bolton, M. D., \& Mckinley, J. D. (1997). Geotechnical properties of fresh cement grout-pressure filtration and consolidation tests. Géotechnique, 47(2), 347-352

Das, B. M. (2010). Principles of Geotechnical Engineering (7th ed.). Cengage Learning

Dupain, R., Lanchon, R., \& Saint Arroman, J. C. (1995). Granulats, Sols, Ciments et bétons, Caractérisation des matériaux de Génie Civil par les essais de laboratoire. Edition Casteilla

Hendrickx, R., Roels, S., \& Van Balen, K. (2010). Measuring the water capacity and transfer properties of fresh mortar. Cement and Concrete Research, 40(12), 1650-1655. http://doi:10.1016/j.cemconres.2010.08.002

Hughes, D. C. (1985). Pore structure and permeability of hardened cement paste. Magazine of concrete research, 37(133), 227-233. http://dx.doi.org/10.1680/macr.1985.37.133.227

Josserand, L., Coussy., O., \& de Larrard, F. (2006). Bleeding of concrete as an ageing consolidation process. Cement and Concrete Research, 36(9), 1603-1608. http://dx.doi.org/10.1016/j.cemconres.2004.10.006

Josserand, L., \& de Larrard, F. (2004). A method for concrete bleeding measurement. Materials and Structures, 37, 666-670. http://dx.doi.org/ 10.1007/BF02480511

Josserand, L. (2002). Ressuage des bétons hydrauliques. Thèse de Doctorat à l'ENPC, France

Marliere, C., Mabrouk, E., Lamblet, M., \& Coussot, P. (2012). How water retention in porous media with cellulose ethers works. Cement and Concrete Research, 42(11), 1501-1512. http://dx.doi.org/10.1016/j. cemconres.2012.08.010

Mehta, P. K., \& Manmohan, C. (1980). Pore size distribution and permeability of hardened cement paste. 7th International congress on the chemistry of cement, Paris, France, 3(7), 1-5

Muskat, M. (1937). The Flow of Homogeneous Fluids through Porous Media. New York: McGraw-Hill Book Company Inc.

Neville, A. M. (1995). Properties of Concrete (4th ed.). Harlow Longman.

Norme NF EN 196-1. (2006). Méthodes d'essais des ciments - Partie 1 : détermination des résistances mécaniques. Avril 2006

Norme NF P 18-451. (1981). Essais pour béton frais - Partie 2 : essais d'affaissement

Perrot, A. (2014). Matériaux cimentaires : De la caractérisation à la mise en oeuvre, HDR. Matériaux composites et construction. Université de Bretagne Sud, Lorient, France. Retrieved from http://hal.univ-brest.fr/tel-01112974v1

Perrot, A., Lanos, C., Estellé, P., \& Mélinge, Y. (2006). Ram extrusion force for a frictional plastic material: model prediction and application to cement paste, Rheol. Acta, 45, 457-467. http://dx.doi.org/101007/ s00397-005-0074-y

Perrot, A., Rangeard, D., Picandet, V., \& Melinge, Y. (2013). Hydro-mechanical properties of fresh cement pastes containing polycarboxylate superplasticizer. Cement and Concrete Research, 53, 221-228. http://dx.doi.org/10.1016/j.cemconres.2013.06.015

Picandet V., Amziane, S., \& Tchamba, J. C. (2005). Study of early shrinkage, hydraulic pressure and conductivity of cement paste. Concreep 7 Conference. Nantes 05, France, pp 405-410

Picandet, V., Rangeard, D., Perrot, A., \& Lecompte, T. (2011). Permeability measurement of fresh cement paste. Cement and Concrete Research, 41, 330-338. http://dx.doi.org/ 10.1016/j.cemconres.2010.11.019

Pierre, A., Perrot, A., Picandet, V., \& Guevel, Y. (2015). Cellulose ethers and cement paste permeability. Cement and Concrete Research, 72, 117-127. http://dx.doi.org/10.1016/j.cemconres.2015.02.013

Powers, T. C., Copeland, L. E., Hayes, J. C., \& Mann, H. M. (1955). Permeability of portland cement paste. ACI Journal Proceedings, 51(11), 285-298 
Rangeard, D., Perrot, A., Picandet, V., Mélinge, Y., \& Estellé, P. (2015). Determination of the consolidation coefficient of low compressibility materials. Materials and Structures, 48(5), 1475-1483. http://dx.doi.org/ $10.1617 /$ s1 1527-014-0247-1

Tchamba, J. C. (2008). Contribution à l'étude expérimentale du comportement des matériaux cimentaires au jeune âge: pression; rhéologie et perméabilité. (Unpublished doctoral thesis). Université de Bretagne Sud, Lorient, France

Ye, G. (2003). Experimental Study and Numerical Simulation of the Development of the Microstructure and Permeability of Cementitious Materials (Doctoral Thesis, Delft University of Technology, Delft, The Netherlands). Retrieved from http://repository.tudelft.nl/view/ir/uuid\%3Aed9166f3-dc6e-4c6c-bd06-8d43 c6354558/

Yim, H. J., Kim, J. H., Kwak, H.-G., \& Kim, J. K. (2013). Evaluation of internal bleeding in concrete using a self-weight bleeding test. Cement and Concrete Research, 53, 18-24. http://dx.doi.org/10.1016/j.cemconres. 2013.05.015

\section{Copyrights}

Copyright for this article is retained by the author(s), with first publication rights granted to the journal.

This is an open-access article distributed under the terms and conditions of the Creative Commons Attribution license (http://creativecommons.org/licenses/by/3.0/). 